\title{
An Investigation into the Causes and Effects of Women Political Underrepresentation in Ogun State, Nigeria
}

\author{
Elias Mabel Oyindamola, Prof. Azeez Olaniyan \\ Ekiti State University, Ado-Ekiti, Nigeria
}

\begin{abstract}
Nigeria has been described as a patriarchal nation because of the low level of women political participation. Women are expected to partake in governance and the decision-making process of a nation because their challenges can only be understood and effectively solved by themselves. Therefore, it has become necessary to identify the causes and understand the effects of low political under representation of women in Nigeria. This study employed the use of primary and secondary data to identify the causes and effects of women's underrepresentation in the political sphere. Primary data was obtained by administering 100 questionnaires and interviews at Obafemi/Owode Local Government in Ogun state; 97 of these questionnaires were returned. The secondary sources of information include published journals, theses, papers from academic conferences, and an online repository of information. This study identified some causes of women's political underrepresentation in Nigeria. The effects of poor representation of women in governance and decision-making process were discussed. Possible solutions identified to the identified challenges were highlighted and concrete recommendations were made.
\end{abstract}

Keywords: Patriarchal; Women; Political-Participation; Political-Underrepresentation; Political-Sphere

\section{INTRODUCTION}

$\mathrm{W}$ omen's participation in governance has experienced a global rise over the past decades but they are still low compared to that of men; women hold only $23.8 \%$ of all seats in the parliaments and senates in the world despite being half of the global population (Radu, 2018). As of January 2019, globally, only $20.7 \%$ of government ministers are women, 11 are serving as head of States, and 12 as Head of Government (UN Women, 2019). The African continent is not left behind in terms of the influence of women in governance. Rwanda, Seychelles, Senegal, and South Africa are among the top ten countries in the world in terms of female political participation (IPU, 2015). However, the same cannot be said of Nigeria; Nigerian women are still suffering from discriminations in the familial and societal settings. According to Nwachukwu (2018), the political representation of women in Nigeria is still a far cry from the level expected despite the nation being signatories to international conventions on gender equality. Statistics from the recently concluded 2019 general elections showed a decline in the number of women elected into public offices. The Fact Sheet presented by the Centre for Democracy and Development (CDD) revealed that only 62 women were elected into offices (equivalent to 4.17 percent of the elected officials); this value falls below the value $(5.65 \%)$ recorded for 2015 elections (Onyeji, 2019). Onyeji (2019) further revealed that out of 235 women $(12.34 \%$ of the candidates) that contested for a seat in the senate, 7 women $(6.42 \%)$ were elected; similarly, 533 women participated in the contest for a seat in the House of Representatives, only 11 (3.05 percent) were elected. Although there has been a palpable improvement in the number of women participating in elections, the percentages of women that won the elections are still low. Therefore, it has become necessary to look into the factors responsible for the low representation of women in the elective and appointive offices, the effects it has on women's development, and therebyproffer possible solutions to this ugly menace in Nigeria.

The study employed both primary and secondary data to analyze data and draw empirical conclusions regarding the causes and effects of women's low participation in governance. The primary data for this study was obtained through questionnaires and semi-structured interviews distributed to the people of Obafemi Owode Local government in Ogun State. The researcher adopted purposeful sampling in which 100 men and women which consist of businessmen and women, politicians, public/civil servants, and students. The principat sources of secondary data were information gathered from textbooks and published materials, which include peer-reviewed journals, academic conference publications, newspaper publications, and articles sourced from the internet.

\section{WOMEN IN NIGERIA AND THEIR POLITICAL REPRESENTATION FROM 1999}

Women form a significant percentage of a nation's population and as a result, should be integrated into governance and decision making. According to the World Population Review (2020), Nigeria's population is projected at 206,933,389; with the percentage of women estimated at $49.33 \%$. Women can lead and contribute to national development. However,Babatunde, Ifedayo, and Ishola (2013) cited that only a few women 
have been elected to occupy the male-dominated legislative and executive positions. Despite the awareness and nationwide campaign to promote women's participation in governance, there has been no significant improvement in the numbers of women holding elective or appointive positions. The nation's democratic development is in grave danger if the low level of involvement of women in public decision-making persists. Therefore, it becomes imperative to identify such factors inhibiting the participation of women in politics in Nigeria. Several factors have been identified to hinder women's political participation and representation.

\section{CAUSES AND FACTORS OF WOMEN POLITICAL UNDERREPRESENTATION}

Nigeria returned to democracy in 1999 after nearly 16 years of uninterrupted military dictatorship. During this period of military rule, the public offices were dominated by men. The return of democracy offered a glimpse of hope for women's inclusiveness in governance and decision making. However, 21 years after 1999, the nation has not recorded any significant improvement in the level of participation of women in governance. Statistics from IRI (2015) revealed that from 1999 to 2015, there have been 31 senators, 98 House of Representatives members, and 303 state House of Assembly members that are women. It was reported in 2019 that women experienced the lowest women's participation in politics in the

2019 general elections; only 2970 women were on the electoral ballot $(11.36 \%)$, out of this figure, only 62 women were elected (CDD, 2019). There has been no female governor or president. In 2019, Nigeria ranked 181st out of 193 countries in the world in terms of political participation (Punch, 2019). This shows that the nation is lagging in terms of the participation of women in governance and decision-making. Some of the causes and factors of women political underrepresentation include the followings:-

\section{RELIGIOUS CONSTRAINT}

Religion has been attributed to be one of the main factors restraining women from participating in politics and governance. It is believed that the major religions in Nigeria, Christianity and Islam, have relegated women's role to that of a subordinate. In a bid to establish this claim, Halimat and Adelowo (2018) quoted the Holy Bible and the Quran:

"Submitting your selves' one to another in the fear of God. Wives, submit yourselves unto your husbands, as unto the Lord. For the husband is the head of the wife, even as Christ is the head of the Church: and he is the Savior of the body. Therefore, as the church is subject unto Christ, so let the wives be to their husbands in everything (Ephesians 5 verses 21-24)"
"Men are the protectors and maintainers of women, because Allah has given the one more (strength) than the other, and because they support them from their means. Therefore the righteous women are devoutly obedient, and guard in (the husband's) absence what Allah would have them guard (Qur'an 4:34)".

Religious inclinations have subdued the voice of women and have made them mere spectators in the society. Oni (2004) opined that women are unable to challenge the opinions of men in the society because of the fear of going against their religious injunctions; he added that religion has made women submissive to their husbands. Daniel and Faith (2013) posited that many religious leaders share the sentiment that women who engage in public affairs or political activities as wayward, immoral, and loose; they are admonished to steer clear from politics. Erunke and Shuaibu (2013) added that within the religious sphere, participating in governance is often seen as an engagement capable of defiling one's spirituality and break one's home. This attitude not only negates women's abilities and knowledge, but it also deprives them of the opportunity to serve their fatherland.

\subsection{Cultural Orientations}

According to Halimat and Adelowo (2018), Nigeria is a state with diverse ethnic groups that are characterized by many cultures that discourage women's participation in politics. The central theme of these cultures is a belief system that women belong to the home. Fasugba (2000) suggested that this system has relegated women's duties to childbearing and home management, thereby preventing them from engaging in societal roles. Frontline Women (2007) believed that it is a widespread belief that men are the decision-makers and women belong to the kitchen; a statement that was justified by President MohammaduBuhari's recent claim that his wife belongs to the kitchen and the other room (BBC, 2016). Ogbogu (2012) disclosed that politics exposes women to close interactions with men, which is seen as culturally unacceptable. Olufade (2013) and Akiyode-Afolabi and Arogundade (2003) condemned African cultural norms for preventing women from participating in social interactions and political functions that might develop their confidence and provide a platform for their voice to be heard. In a nutshell, our culture has influenced our political system in a way that is detrimental to women and democratic development in the nation.

\subsection{Education}

Education has been seen as a way to emancipate women from all social, intellectual, and political barriers. This is because of the awareness and enlightenment it creates; it also stirs the desire to be meaningful to society. Adedokun (1998) cited in Fapohunda (2009) attributed the poor participation of women in governance to their educational status, he believed that men are more educated than their female counterparts, especially in Northern Nigeria. Akpede, 
Eguvbe, Akpamu, Asogun, Momodu, and Igbenu (2018) opined that poor attitude of African parents to the education of female children is the greatest barrier to the education of female children and hence the reason for persistent male dominance. Okpilike and Abamba (2004) referenced the result ofa survey conducted by the National Planning Commission which revealed that $50 \%$ of women in Nigeria has no formal education; they concluded that

$50 \%$ of women are automatically disqualified from contesting any appointive or elective position since formal education is a prerequisite for contesting for any position.

\subsection{Constitutional and Legal Constraints}

The constitution has been branded by some scholars as unfriendly to women and that it impedes their participation in governance and decision making. Scholars such as Ityavyar (2007) and Oke (2015) claimed that the constitution has always excluded female legitimacy right from the colonial era. Oke (2015) fingered the Clifford constitution of 1922, the Richard Constitution of 1946, the Macpherson Constitution, and the Lyttleton Constitution of 1954 for restricting the electorate to adult males. He added that it was not until 1979 that the right to vote was extended to all Nigerian women.

Although the 1999 constitution in its sections 40, 42 (1) and 77 (2) granted all Nigerians the liberty to participate freely in political activities irrespective of sex, tribe, or political inclination (Constitution of FRN, 1999), women are still politically enchained. Leke (2015) highlighted some flaws in section 26 (2), 55 (1), Police Act (Cap 158), Section 18 of the Marriage Act (Cap 218 LFN 1990); he lamented that these sections do not protect the interest of women neither does it promote gender equality. This statement was corroborated by Agbaegbu (2000) when he regarded the constitution as an instrument that aids political inequality between men and women. Conyok (2015) added that the minimal rise in gender participation has been limited to appointive positions. The situation of women remains the same; the Nigerian constitution and Nigerian weak legal framework are to be blamed as the obstacles to women's political ambition (Makama, 2013).

\subsection{Political Atmosphere in the Country}

The way politics is practised in Nigeria discourages a lot of women. Nigerian politics is characterised by thug invapions, violence, intimidation, and godfatherism occasioned by desperation. Eyinade (2010) believesthat this kind of environment makes the participation of women in politics a dangerous venture. Agbalajobi (2010) asserted that the dangerous political climate in Nigeria has limited politics to those who have the wherewithal to survive its rigours. He believes that women do not have a choice than to step aside for men because of their soft and fragile nature. Apart from this, Ogbogu (2012) claimed that the structure and policy of political parties in Nigeria do not give room for women to advance in politics. He further asserted that most political meetings are held at unsociable hours at hotels, clubs, and secluded places that are not conducive for responsible women. This in-conducive political environment deters women from participating actively in decision making and party politics.

\subsection{Perception from other Women}

Agbaje (2019) identified the perception of women on the political ambition of their counterparts as one of the barriers to women's participation in governance. The author believes that some women would rather vote men because they see women as politically inept and their participation is seen as being overambitious. Women form a significant percentage of the nation's population; failure of women to support their fellow female contestants may be one of the reasons why they score low votes during elections.

\subsection{Societal Violence and Conflicts}

The aftermath of wars, violence, and political turmoils have a devastating effect on women. Women and children are the most vulnerable during uprisings, and the gruesome experiences they suffer tend to isolate them from the society. In her description of the psychological and emotional effects of conflicts on women, Gladys (2016) cited that the posttraumatic stress disorder that happens when a woman suddenly loses her husband, child or family member to conflict makes them so engrossed with providing for their family and more disinterested in political affairs. Mutunga (2004) cited in Gladys (2016) claimed that women are often targeted during conflicts, he attributed the increase in sexual violence to the weakening of social structures, and the poor justice system in the country which has made the victims not to speak up. The victims of these brutalities and horrors are often left damaged; they lose their self-esteem and self-respect, the victims find it difficult to live a normal life because of the feeling of dejectedness.

\subsection{Financial Implication}

Nigerian politics is not for the poor or the middle class. This is evident by the high cost of purchasing parties' expression of interest form, nomination form, and of funding election campaigns. Eyinade (2010) claimed the cost of the party nomination form is very high and has proven to be a major obstacle for women's participation in politics. Adebowale (2016) confirms that the game of politics is for the extremely rich class; he further asserted that without the affluence or the support of a political godfather, it is difficult to engage in Nigerian politics. According to Mcfadden and Keshia (1999), most women are financially incapacitated to contest with men for positions because of their poor educational background and relegation to domestic duties.

\subsection{Tribal Affiliations}

Women are bound to marry from any tribe. According to marriage practice in Nigeria, a woman after marriage legally and culturally belongs to the tribe of the husband. This set of 
women are not often accepted and supported because of their origin of birth. Recently, the appointment of Nimi Akunkugbe (a woman born in Rivers but married to an Ondo indigene) as an ambassadorial candidate of Ondo state generated public outcry because she was not born in the state (Johnson, 2020). Daniel and Faith (2013) described this as non-indigene syndrome whose root can be traced to the pre-colonial Nigerian societies. Iloh and Ikenna (2009) asserted that this problem needs to be addressed to prevent the alienation of women who falls into this category.

\subsection{Personal Attitudes}

Most women are inherently lazy and afraid to step out of their comfort zone. A lot of them are satisfied with the status of housewives and would not engage in activities outside their matrimonial homes. Fapohunda (2009) claimed that this lazy attitude of women could be partly attributed to their lack of proper education and also due to the burden of being the breadwinner of the family. He believes that family responsibilities take their toll on them and often make them disinterested in politics. Apart from this, the perception of women about politics inhibits their participation in governance. Onifade (2013) citing Mohanty (1988) posited that most women believe that it is impossible to venture into politics and still maintain a happy home, they belief politics is meant for women with marital failures because of the rigorous nature of the meetings, campaigns and fundraising events that often keeps them far away from their family. Another popularly held opinion is that women cannot survive the violent nature of politics in Nigeria. These perceptions affect the attitude of women towards governance and make them lose interest in joining a political party or in contesting for a political position.

\subsection{Colonialism}

Colonialism has been seen by many as one of the factors which contributed to the dominance of men in society. Dadirep (1995) cited in Ogunjemilua and Familugba (2015) suggested that the model of governance adopted by the British colonial masters led to the neglect of women. Omolewa (2002) criticised the colonial masters for promoting menwomen inequality in their system of education which deliberately alienated women from educational and economic opportunities. The inability of women to compete with men educationally and economically affects their participation in politics.

\section{EFFECT OF WOMEN UNDER- REPRESENTATION ON DEVELOPMENT IN NIGERIA}

Women's low participation in decision-making makes them unable to address their basic problems and needs in society. Men have shown little or no interest in addressing the challenges of women in society probably because it might threaten their dominance. Apart from this, a large number of women need to be included in governance because they have roles and responsibilities that cannot be overlooked. Their poor participation in governance is therefore expected to have dire consequences on their development and general well-being

\subsection{Effect on Women's Interest}

Women have special needs that cannot be identified by men. They need to be part of decision making that will promote their welfare and interest. Shimelis (2015) pointed out women are needed in representative institutions to articulate their interests because it often conflicts with those of men. Phillips (1995) admitted that there is a connection between the number of women elected into government and the advancement of women's interest; he claimed that women are more likely to speak, advocate and act on behalf of women and children. Wagnerud (2009) added that women pay attention to issues concerning women such as pay equity, violence against women, health care, family policy, and divisions in paid and unpaid work. If there had been a sufficiently high number of women in the legislative arm of the government perhaps the lingering issues that involve genital mutilation, domestic violence, child marriage, child and women trafficking would have been made priority and reduced to the barest minimum.

\subsection{Lack of Role Models and Mentors to Look Up To}

Women need political figures to look up for inspiration or advice. Bhalotra, Irma, and Lakshmi (2015) proposed that a deficiency of the female role model is responsible for the persistence of gender gaps in leadership positions. Lakshmi (2019) affirmed the importance of the role model effect; she added that more women may be inclined to vote for female candidates if women start to record electoral successes. The inability of women to win major positions during elections affects the participation of women contesting for similar votes in subsequent years. Eweniyi (2019) reported that Dr.ObyEzekwesili, a female candidate of the Allied Congress Party of Nigeria (ACPN) stepped down as their presidential candidate four weeks into the election after months of rigorous campaign. If a woman had previously contested and won the presidential election, she would have been encouraged to contest. Therefore, the inability of women to take up leading positions in the country harms female participation in elections and governance.

\subsection{A Dent on our Democratic Process}

Haque (2003) believed that the legitimacy, validity, and trustworthiness of democracy are affirmed when women are given unlimited freedom to participate in politics. Melesse and Ojulu (2014) described women involvement in political leadership and governance as an ingredient for promoting peace and democratic development in a country as a whole. Sandra (2018) added that the equitable participation of women in public life is essential to building and sustaining strong and vibrant democracies. She added that women's political governance brings tangible gains to democracy 
through their greater responsiveness to citizen's needs, their increased cooperation across party and ethnic lines, and their quest for a more sustainable future. Therefore, a democratic institution without the full involvement of women is regressive and the nation that practises such cannot experience growth and development.

\subsection{Effect on Development of the Nation.}

Throughout the world, the untapped potentials and ability of women's leadership are gaining attention. A critical look at the political history of Nigeria from 1999 to date shows the roles played by some exceptional women in advancing the growth of the economic sector, the health sector, and other sectors. Uchegbu (2006) noted the achievements of Okonjo-Iweala and Dora Akunyili in the economic sector and health sector respectively and submitted that their contributions to the development of Nigeria are worthy of emulation. The heroics of Doctor Adadevoh in preventing the spread of Ebola cannot be forgotten too soon (Will,

2014). History has shown the significant impact of women in development. For example, Edwin and Carles (2018) attributed the high increase of women's participation in governance to the improvement in the health of Canadian people; they asserted that women promote civil rights and social equity. Brady (2009) highlighted that women are more committed to a more equal distribution of valuable resources than men. Sandra (2018) claimed that women's involvement in legislation increases policy making that emphasizes on quality of life and reflects the priorities of families, women, and ethnic and racial minorities. Nigeria has benefitted from the exceptional qualities and abilities of women. Allowing men's dominance to thrive is hampering the development of this nation.

\section{DISCUSSION OF FINDINGS FROM THE QUESTIONNAIRES AND INTERVIEW}

Questionnaires and interviews were used to obtain the responses of people on their perception of the causes and effects of women's underrepresentation in governance in Nigeria. Two hypotheses were set in line with the objectives of this study, which is to evaluate the causes and effects of the underrepresentation of women in the political arena. This section presents the analysis of the hypothesis based on the responses obtained from the questionnaires and interviews.

Hypothesis One: Religion, Education, Nigerian Culture, and Issues relating to Gender Discrimination have a Great Influence on Women's Political Participation in Ogun State, Nigeria.

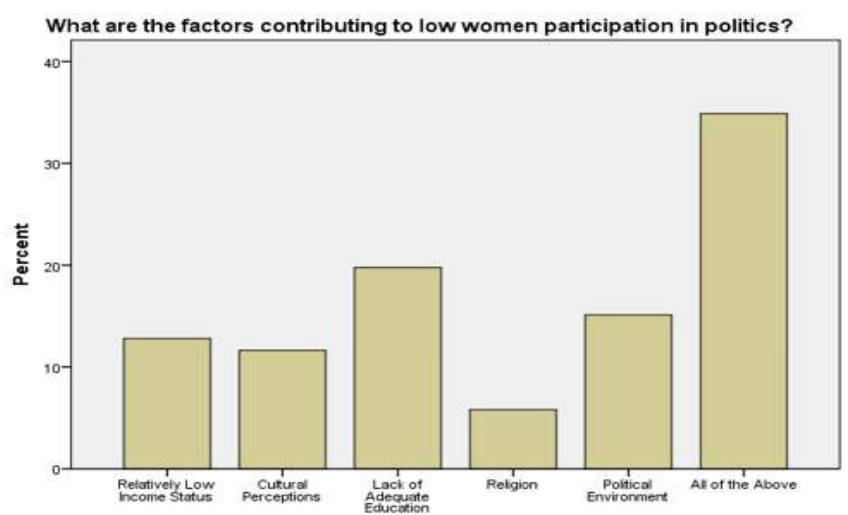

Figure 1. Factors Contributing to Low participation of Women in Governance

Figure 1 shows the opinion of the respondents on the factors contributing to the low participation of women in governance and decision making. 11 respondents (12.8\%) cited low income, 10 respondents $(11.6 \%)$ pointed to culture and traditions, 17 respondents (19.8\%) selected lack of adequate education, 5 respondents $(5.8 \%)$ cited, 13 respondents $(15.1 \%)$ chose the political environment, 30 respondents $(34.9 \%)$ selected all the options as the cumulative cause for women's low participation in politics. These responses justify the fact that religion, education, Nigerian culture, low-income status, and the political environment have a great influence on women's political participation in Nigeria. Culture, education, and religion are the leading cause of gender discrimination in this country. Even though women promote cultural practices and are always at the forefront of religious activities; cultural and religious perceptions have stifled their freedom to participate in politics. The result obtained from this work is consistent with the findings of other authors: the work of Halimat and Adelowo (2018) showed that religion contributes to female subordination. Fasugba (2000) deduced from his studies that the poor participation of women in societal roles and political functions can be linked to the patriarchal nature of our culture and tradition. Akpede, Eguvbe, Akpamu, Asogun, Momodu, and Igbenu (2018) blamed the poor participation of women in politics on their low level of education, and Fapohunda (2009) inferred from his studies that poor education of women is to be blamed for the gender imbalance in the country.

Some respondents in the interview section cited various reasons responsible for the low participation of women in Nigerian politics. One respondent claimed that most women lack self-confidence because they consider themselves inferior to men. Another respondent cited the fear of losing elections after investing a lot of money as one of the reasons why the political scene has not been dominated by women. Most of the respondents claimed that women have not been properly educated; some cited oppression from husband and colleagues while others blamed the influence of godfatherism. Another point that was highlighted is the lack of constitutional enforcement; it was 
believed that there are no rules and regulations that have been put in place to support women's political ambitions.

Hypothesis Two: Poor Participation of Women in Politics affects their Interests, Well- being, and the Development of the Nation.

Usinga five-point Likert scale, the following information was obtained on the effect of women's poor participation in politics on their interests, well-being, and the nation's development.

Table 1: The Effect on Interest and Well-Being

Non-participation of women in politics affects their interest and well-being in society

\begin{tabular}{|ll|c|c|c|c|}
\hline & Frequency & Percent & $\begin{array}{c}\text { Valid } \\
\text { Percent }\end{array}$ & $\begin{array}{c}\text { Cumulative } \\
\text { Percent }\end{array}$ \\
\hline Valid & Strongly Agree & 13 & 13.1 & 14.0 & 14.0 \\
& Agree & 34 & 34.3 & 36.6 & 50.5 \\
Not Sure & 18 & 18.2 & 19.4 & 69.9 \\
Disagree & 21 & 21.2 & 22.6 & 92.5 \\
Strongly & 7 & 7.1 & 7.5 & 100.0 \\
Disagree & & & & \\
No Entry & 4 & 4.0 & & \\
Missing & 3 & 3.0 & & \\
& & & & \\
Total & 97 & 100.0 & & \\
\hline
\end{tabular}

Source: Field Work, 2019

Table 1 revealed that 47 respondents $(50.6$ percent of the total respondents) either agreed or strongly agreed that women's interest and well-being in society is being affected by their non-participation in politics. 28 respondents (19.4 percent of the total respondents) were not sure, while 21 respondents (30.1 percent of the total respondents) are of a contrary opinion. One of the effects of non-participation or poor participation of women in politics is that their interests and well-being are not well represented. Many believe that only women can properly identify their challenges and as well as promote their interests. Without women to represent their gender, this interest might not be served at the expected level.

Table 2: Effect on Poor Development in Nigeria

Poor development in Nigeria can be linked to the gender imbalance between men and women in the political sector?

\begin{tabular}{|ll|c|c|c|c|}
\hline & & Frequency & Percent & Valid Percent & $\begin{array}{c}\text { Cumulative } \\
\text { Percent }\end{array}$ \\
\hline Valid & Strongly Agree & 23 & 23.2 & 24.5 & 24.5 \\
& Agree & 37 & 37.4 & 39.4 & 63.8 \\
& Not Sure & 19 & 19.2 & 20.2 & 84.0 \\
& Disagree & 14 & 14.1 & 14.9 & 98.9 \\
& Strongly Disagree & 1 & 1.0 & 1.1 & 100.0 \\
& & & & \\
No Entry & 3 & 3.0 & & \\
Missing & 3 & 3.0 & & \\
& & & & \\
Total & 100 & 100.0 & & \\
\hline
\end{tabular}

Source: Field Work, 2019
Table 2 shows that 60 respondents $(63.8$ percent of the respondents) believe that gender imbalance is responsible for poor development in Nigeria. However, 15 respondents ( $15 \%$ of the respondents) do not share this sentiment. It can be inferred from these statistics that poor development in Nigeria can be linked to gender imbalances especially in the political sector of the country. Men were found to dominate the political sphere with few seats reserved only for a few women. Therefore, the attainment of gender parity should be a major goal of the nation if sustainable development is considered a necessity.

In the interview section, different examples were cited to justify the fact that women's interest has not been served in Nigeria. These include the early marriage of teenage girls, gender mutilation, rape, and other sexual related offenses on women and the girl-child. It was lamented that offenders have always gone scot-free because of the negligence of the maledominated legislative, judiciary, and executive arm of the government.

\section{CONCLUSION AND RECOMMENDATION}

This work has provided an exhaustive study on the political marginalisation of women in Nigerian politics and its cause and effect. The conclusion drawn from this study is that culture, poor education, religion, poverty (low-income status), political environment, poor constitutional backing, perceptions about women, societal violence and conflicts, tribal affiliations and personal attitudes of women are to be blamed for poor women political representation in Nigeria. The study also revealed that low women participation in politics has affected their interest and well-being, and also the democratic development of the nation as a whole. In a nutshell, this research work has been able to identify the reasons why women have been benchmarked in politics and the effect of the unequal representation of women in Nigeria.

In the light of this study, it is recommended that gender equality should be enforced in Nigeria, cultural and religious barriers should be removed; traditional and religious leaders should be equipped to educate their members on the need for equal representation in all spheres. All the clauses in the constitution that promotes male dominance should be removed. Workshops and campaigns should be organised to change the attitude and perceptions of women about politics and the need for women to be equally represented. Women's education should be promoted to balance the deficit between male and female enrolment in schools. The barrier of financial constraints should be removed at all levels in politics. For a start, women should be allowed to pick up forms for political offices for free. Their party should fund their campaigns to increase their desire to participate in politics. Violence, thuggery, intimidation of opposition parties, vote-buying, and godfatherism should be curbed in Nigerian politics to make elections free, fair, and credible. When women are given equal 
opportunities to participate in politics, there will be no limit to the level of development they will bring to the nation.

\section{REFERENCES}

[1] Adebowale, O. (2016). Cost of Politics in Nigeria, Westminster Foundation for Democracy, Retrieved $28^{\text {th }}$ August, 2019 from https://www.wfd.org/network/nigeria/cost-of-politics/

[2] Akiyode-Afolabi, A. \&Arogundade, L. (2003). Gender Audit 2003. Election and Issues in Women's Political Participation in Nigeria. Lagos, Women Advocates Research and Documentation Central (WARDC).

[3] Agbalajobi, D. (2010). Women's Participation and The Political Process in Nigeria: Problems and Prospects. African Journal of Political Science and International Relations, 4(2), 75-82

[4] Agbaje, F. (2019). Reflections on the Challenges Facing Women in Contemporary Nigeria Politics. Journal of International Politics, 1(1), 32-38.

[5] Akpede, N., Eguvbe, A., Akpamu, U., Asogun, A., Momodu, M., \&Igbenu, N. (2018). Parents Attitude and Practice towards the Girl Child Education in Esan West Local Government Area of Edo State in Nigeria, Journal of Women's Health and Reproductive Medicine, 2 (1)

[6] Agbaegbu, T. (2000). Nigerian Women: The Struggle since Independence, The Gains and The Losses in News Watch Magazine, October 2

[7] BBC (2016).Nigeria's President Buhari: My wife belongs in kitchen. Retrieved September $11^{\text {th }} 2020$ from https://www.bbc.com/news/world-africa-37659863

[8] Bhallotra, S., Clots-Figueras, I., \& Lakshmi I. (2015). Role Model Effects? Women's Political Participation in India. Retrieved 1st August, 2019 from http://www.iser.essex.ac.uk/blog/2015/07/06/role-model-effectswomen-s-political- participation-in-india

[9] Brady, D. (2009). Rich Democracies, Poor People; How Politics Explain Poverty, Oxford, UK, Oxford University Press.

[10] Center for Democracy and Development (CDD) (2019). March 2019 Report. Retrieved July,20th from https://www.cddwestafrica.org/how-women-fared-in-the-2019elections/ Constitution of the Federal Republic of Nigeria, (1999). Retrieved $12^{\text {th }}$ October, 2019 from

[11] https://publicofficialsfinancialdisclosure.worldbank.org/sites/fdl/fil es/assets/law- library-files/Nigeria_Constitution_1999_en.pdf

[12] Conyok, R. (2015). The Critical Role of $\bar{W}$ omen in Nigeria politics; Declarations and Reservations. United Nations Treaty Collection, Retrieved October 10, 2019 from https://treaties.un.org/pages $/$ ViewDetails.aspx?src=TREATY\&mtd sgno $=$ XXVII-7 $-\mathrm{d} \&$ chapter $=27$

[13] Daniel, E., \& Faith O. (2013). Women in Governance and Sustainable Democracy in Nigeria, 1999-2012. Journal of Economics \& Sociology,6 (1), 89-107. Edwin, N., \&Carles M. (2018). The effect of Women in Government on Population

[14] Health: An Ecological Analysis among Canadian Provinces, 1976-2009. SSM Population Health, 6, 141-148. DOI: 10.1016/j.ssmph.2018.08.003

[15] Erunke, C., \&Shuaibu, U. (2013). The Role of Women in Nigerian Politics: Interrogating the Gender Question for an Enhanced Political Representation in the Fourth Republic. Afro Asian Journal of Social Sciences 4 (4.2)

[16] Eweniyi, O. (2019). Dr ObyEzekwesili Steps down from the Nigeria Presidential race.

[17] Konbini Channels, Retrieved $1^{\text {st }}$ August, 2019 from https://www.konbini.com/ng/lifestyle/dr-oby-ezekwesili-stepsnigerian-presidential- race

[18] Eyinade, A. (2010). Women and Participation in Nigeria: The Imperative of Empowerment, The Africa Executive. $\begin{array}{lllrr}\text { Retrieved } & 18 & \text { July, } & 2019 & \text { from }\end{array}$
www.africaexecutive.com/downoloads/womenandparticipationinN igeria.pdf

[19] Fapohunda, T. (2009). Women Emancipation for Sustainable Development in Nigeria: Myths, Realities and Challenges. International Journal of Development Studies, 4 (4) Fasugba, O. (2000). Vacancy; Tough Women only. The punch $(2 / 5 / 2000)$ Lagos. The Punch Press P.25.

[20] Frontline Women (2007). Women and the 2007 Elections. Frontline Magazine, 2 (1) Gladys, K. (2016). Building Women's Capacity for Peace building in Nigeria.

[21] American Research Institute for Policy Development, 4 (1), 31-46. Halimat, T.\&Adelowo, S. (2018). The Affirmative Action and

[22] Women Participation in Politics in Nigeria: An Assessment Study on the Legal Constraint. Kwasu Journal of Humanities, 1 (1), 71-86.

[23] Haque, M. (2003). Citizen Participation in Governance through Representation: Issue of Gender in East Asia. International Journal of Public Administration, 26, 569-590

[24] Iloh, E., \&Ikenna, M. (2009), Electoral Process and Gender Discrimination in Nigeria: A Case Study of 2003 and 2007 General Elections. Journal of Sustainable Development in Africa, 10 (4), 113-128.

[25] IPU (Inter-Parliamentary Union). (2015). Women in Parliament: 20 Years in Review.

[26] Geneva: IPU. Retrieved 22 ${ }^{\text {nd }}$ September, 2019 from https://www.ipu.org/resources/publications/reports/201607/women-in- parliament-20-years-in-review/

[27] IRI (2015). 2015 Nigeria national Elections: Gender Disparity in Nigeria's General Elections 1999-2015, Retrieved July $19^{\text {th }}$ from https://www.iri.org/2015\%20Nigeria\%20Election\%20Observation $\% 20$ Report/1/assets/basic-html/page $40 . h t m l$

[28] Ityavyar, D. (2007). Gains of Women Activism in Nigeria: 19602007. Paper presented at the National Conference on Women in Governance at the Obudu Cattle Ranch, Cross Rivers, October 2nd- ${ }^{\text {th }}$

[29] Johnson, D. (2020). Ondo Ambassadorial Nominee-Ekimogun Roundtable Backs Akinkugbe, Vanguard Newspaper, Retrieved July $20^{\text {th }}$ from https://www.vanguardngr.com/2020/07/ondoambassadorial-nominee-ekimogun- roundtable-backs-akinkugbe/

[30] Makama, G. (2013). Patriarchy and Gender Inequality in Nigeria: The Way Forward. European Scientific Journal, 9 (17)

[31] McFadden, P., and Keyshia N. (1999). Reflections on Gender Issues in Africa. Harare: Southern African Research and Documentation Centre, Zimbabwe, Mt Pleasant- SAPES Books Publishers.

[32] Melesse, A. \&Ojulu, O. (2014). Assessment of Gender Equality in Ethiopia: The Position of Ethiopian Women's Political Representation from The World, Sub- Saharan Africa, and Eastern Africa Ethiopian Civil Service University. Journal of Law, Policy and Globalization, 3 (4).

[33] Ogbogu, O. (2012). The Role of Women in Politics and in the Sustenance of Democracy in Nigeria. International Journal of Business and Social Science, 3 (18) Ogunjemilua, A., \&Familugba, J. (2015). The Contributions of Nigeria Women Towards

[34] National Development. International Journal for Innovation Education and Research,3 (5).

[35] Oke, L. (2015). Democracy; Women's Political Participation and The Policy Environment in Nigeria.Developing Country Studies, 5 (10).

[36] Okpilike, F., \&Abamba, G. (2014). Sociological Explanations of Male Dominance in Nigerian Party Politics: Implications for Education. British Journal of Education, Society and Behavioural Science,3 (2), 154-162.

[37] Olufade, A. (2013). Nigerian Women, Politics and the National Identity Question. African Educational Research Journal, 1(3), $161-170$ 
[38] Omolewa, M. (2002). Education, in Africa Atlases (Nigeria) ParisFrance, Les Editions J.A.,115-118

[39] Oni, E. (2014). The Dynamics of Women Political Emancipation and Political Participation in Nigeria, Journal of Sustainable Development in Africa, 16(3). Onyeji, E. (2019), 2019 Elections Worst for Nigerian Women in Nearly Two Decades,

[40] Analyses Show, Premium Time Ng, April 20, 2019 https://www.premiumtimesng.com/news/headlines/326243-2019elections-worst- fornigerian-women-in-nearly-two-decadesanalyses-show.html

[41] Philips, A. (1995). The Politics of Presence. Clarendon Press, Retrieved $\quad 1^{\text {st }} \quad$ August, 2019 from https://scholar.google.com/scholar?q=Philips + A. + The+politics + of +presence+1995+Clarendon+Press+Punch (2019). Women in Politics: Nigeria ranks 181 out of 193 Countries, Retrieved June19 2020 from https://punchng.com/women-in-politicsnigeria-ranks-181-out-of-193- countries/

[42] Radu, S. (2018). Women Still a Rare Part of the World's Parliaments, Retrieved 7 June, 2020 from https://www.usnews.com/news/best-countries/articles/2018-0904/women-are-still- underrepresented-in-parliaments-around-theworld
[43] Sandra, P. (2018). Why Women in politics? Women Deliver: National Democratic Institute,Retrieved $1^{\text {st }}$ August, 2019 from https://www.womendeliver.org/2018/why-women-in-politics/

[44] Shimelis, K. (2015). Challenges and Opportunities of Women Political Participation in Ethiopia. Journal of Global Economics, 3 (4).DOI: $10.4172 / 2375-4389.1000162$

[45] Uchegbu, A., (2006). Nigeria: Achievements of Akunyili, OkonjoIweala, Others a Challenge. $\quad$ Retrieved October $25^{\text {th }}$, 2019 from https://allafrica.com/stories/200608100323.html

[46] UN Women (2019). Facts and figures: Leadership and Political Participation. Retrieved $12^{\text {th }}$ July, 2020 from https://www.unwomen.org/en/what-we-do/leadership-andpolitical- participation/facts-and-figures

[47] Wangnerud, L. (2009). Women in Parliaments: Descriptive and Substantive Representation. Annual Review of Political Science, $12,51-69$

[48] Will, R. (2014). Ebola crisis: How Nigeria's Dr Adadevoh Fought the Virus. BBC, Retrieved October $10^{\text {th }}, 2019$ from https://www.bbc.com/news/world-africa-29696011

[49] world Population Review (2020). Nigeria Populaton (Live). Retieved august $15^{\text {th }} \quad 2020$ from https://worldpopulationreview.com/countries/nigeria-population 